\title{
An Overview of the Theoretical Perspectives on Higher Education Financing (Implications for Educational Administration in Nigeria)
}

\author{
Author: Sani Ahmed Yauta \\ Gombe State University, Department of Educational Foundations P.M.B 0127, Gombe, \\ Gombe State, Nigeria. \\ Email: ahmedsaning@gmail.com
}

Phone: +2358035939644

\begin{abstract}
The paper reviewed some theories that explain higher education financing. Some aspect of these theories is compared in terms of the theoretical perspective on financing higher education. The historical viewpoint and the tenant of the theories give an insight and possible solution to higher education financing. The purpose of the paper is to illuminate an important policy issues on financing higher education the world over and to contribute to the general debate on the contribution of theories in explaining the main issue of financing higher education. The paper is presented in three sections; the first section identify the various theories that explain higher education financing, the second parts Discuss the tenet or principles of the identified theories and the third part Explain how these theories explain higher education financing. The paper uses the content analyses to review secondary data collected from published articles. The findings reveals that there a lots of theories that explain higher education financing. Hence recommend human capital theory for effective and efficient theory to be use in explaining higher education financing in Nigeria and the world over.
\end{abstract}

Keywords: Educational Administration, Financing, Higher Education, Theoretical Perspectives. 


\section{INTRODUCTION}

The main concern of this paper is to address the theoretical perspectives of higher education financing. The Paper tries to look at the relevant theories and framework in higher education financing. Consequently the paper will discuss the following areas as its relate to the main issue of concern, the theoretical issues, main argument of the theories, the theoretical framework normally used in explaining the problem of higher education financing. The debate and the evidence provided will be used to analyze and discuss higher education financing which is considered to be a very expensive venture. Many theories have been postulated in order to find solution and understanding of the best method of facing the protracted crises in higher education system, but up till now there is no consensus of opinion among scholars as to the best way of finding solution to the prolonged financial problems faced by higher education the world over. The lingering debate on who should bear the burden of providing adequate finances to higher education system is still persistent in mostly the developing countries like Nigeria. The continue debate on whether education should be considered a "public goods" or "private goods" is still expanding and the consensus is not far fetch among scholars. Therefore, the theories identified below also abide by the current debate and try to provide a plausible argument for or against it. At the end the argument and assumptions behind these theories will help discuss the phenomenon of the identified objectives of the paper. The paper set to review different theories that explain financing higher education institutions, Discuss the tenet or principles of the identified theories and explain how these theories explain higher education financing.

\section{KEY THEORIES THAT EXPLAIN HIGHER EDUCATION FINANCING}

This section of the paper will give an in-depth analysis of the major characteristics of the three widely used theories of higher education financing: discuss one after another starting with the Principal-Agency theory then Human Capital Theory and lastly Political Economy Theory.

\section{The Principal-Agency Theory}

Jensen and Mackling was belief to have developed the theory in 1976 this is to help in explaining and understanding the connection between the Principal in one hand and the Agent on the other hand under a contractual bond to achieve success. 
It has also evolved to address newer concerns in institutional behaviors between the Principal and the Agent. The principal-agency theorizes that Principal and Agent believe whether or not they are at risk and the perception of the benefits of taking action to avoid the risk. This influences their readiness to take action on what to do to achieve the organizational goal (Eisenhardt, 1989; Kivisto, 2005).

The Principal Agency Theory look at the relationship in a contractual form between one or more individual(s) call the "Principal(s)" employs another individual(s) call the "Agent" to execute some service(s) on their behalf which involves allocation some resources to solve some problem and also delegates some power and authority to the agents to act on behave of the principle(s). According to Ahmad, Farley, and Naidoo (2012) the Principle-Agency theory has been established by different researchers to be one of the fundamental answers and a proven theory for researches in Agent-Principal dynamic and it has been found effective to explain the relationship between Principal (government) and the Agent (Higher Educational institutions (HEIs) in solving the perennial problem of higher education financing. Complementing the above postulation Lane and Kivisto (2008) opined that the theory have a wide acceptance and adoption in explaining the higher education financing. It is a known fact that in this contemporary world HEIs are mostly motivated by both economic and political motives to succeed.

Connecting the theory to higher education finance, the Agency theory tries to look at the relationship between Principal(s) and Agent(s) in a contractual manner. The theory is in a way presented to observe whether the contractual agreement(s) between Principal(s) and Agent(s) are adhered to and that the Agent(s) in a way take the required steps and procedure to achieve the desire results as expected by the Principal. The contractual agreement between the principal and agent(s) is mostly built on the assumption that the Agent (s) has all the required competences and capabilities to carry out the task assigned and yield better results for the principal(s) (Bendor, Glazer and Hammond 2001; Kivisto 2005).

The changed paradigm of financing education in general and specifically the higher education in the contemporary competitive market setting has increased the demand for prudent and financial transparency in utilizing and managing the limited public funds. 
The Principal-Agency theory has the capability and strength to offer solutions and has proved to be a fundamental theory for research in Principal-Agent dynamic. The theory is absolutely in a good posture to be applied to study the relationship between "Government" who is the (Principal) and "HEIs" (the agent). The Principal-agency theory is very apt in explaining how the government (Principal) should provide some funds to HEIs (Agent) to perform the function of producing qualify manpower to manage the economy and create job opportunities for the populace. Looking at it in a Nigerian contest where more than 90 percent of the funds allocated to HEIs come from the government/proprietors, hence, a mechanism to checkmate and monitor the activities of the agent(s) (i.e. the institutions) becomes imperative. The theory is used to explain the sources of funds to higher education, which means whether there is a single or double principal. Single principal means only one major financier or sources of income while double principal means multiple financiers or sources of revenues that the higher education depends on. The principal-agency theory explains to a reasonable extent whether the financial resources provided by the government (principal) to HEIs (Agents) are adequate, which is measure by the bench mark postulated by the regulatory bodies of HEIs and by extension the Ministry of Education.

In Nigeria, HEIs are not totally autonomous in the way they generate and spend their funds to a considerable extent, which makes the institutions to be complex in their activity resulting in a bit difficult to monitor. In order to avoid manipulations by the agent the Principal (government) can tie the level of funds released to the agents with their performance. For example the Principal (government) may decide to allocate funds to HEIs according to how successful they meet certain goals set by the government, for example the quantity and quality of graduates out puts produced per year etc (Ingo 2003; Kivisto 2005; Abraham 2012).

Higher performing HEIs or individual academics are going to increase their chances of getting more funding than their less performing counterpart.

Many researchers' uses the Principal-Agent theory to explain its usefulness in finding solution to lingering problems of higher education financing, they include for example Kavistor (2005), Schiller \& Liefner (2007), Daniel and Ingo (2007), Ahmad, Farly and 
Naidoo (2012), Blalark (2012), as a framework to explain higher education financing in the world and Nigeria in particular. Most of this researchers found that both the individual and the organization react negatively toward changes in higher education funding and HEIs-industry relationship are becoming more frequent and are promoted by HEIs administration to provide more sources of funds to the system.

According to Lane and Kivisto (2008) since government (principal) and HEIs (agent) are all public entities, the theory is most suitable for effective and efficient fund utilization for greater achievement. Some justifications are feasible for the suitability and applicability of the principal-agency theory to the financing of HEIs in Nigeria. Firstly, more than $90 \%$ of funding to HEIs is provided by the Government as posit by Ahmed (2015). Secondly, in Nigeria education is consider as a public goods that must be provided by the government, and most a times the outcomes of HEIs are difficult to measure; therefore, agency theory is required to ensure that the performance of the agent is continually measured to align with government objectives. Thirdly, HEIs in Nigeria has a multiple principal hence, the institutions' operate under open and hidden contracts with many funding bodies and government agencies; therefore, a comprehensive framework like agency theory is required in order to monitor and understand the dynamics of multiple principal-single agent relationship.

\section{Human Capital Theory}

Adam Smith in his book titled "Wealth of Nation" written in 1776 discussed extensively on how education acquired by individuals can have a positive impact on the economic growth and development of a nation. Smith (1776) explain that there is no significant difference between resources spent on education and human capital and the one spent on acquiring physical structure.

He believes that they are all important for the economy of a nation to move forward. Human Capital Theory (HCT) has its roots from the work Smith (1776) who believe that there is a need for adequate investment in education and human capital for a sustainable economic growth and development to transpire. 
Schultz (1961), (1963) and (1981) advance the work of Smith (1776), Schultz has been consider to be the father of Human Capital Theory because of his advanced and pioneering works on HCT. This effort represents an original, pioneering approach which gives him the opportunity to model the theory.

The intricacies and perennial problem of Higher education financing worldwide can be explain by the tenant and principles of HCT. This is because the theory explains the rationale behind the knowledge and technical skills acquired by an individual as it influence his productivity in his place of work. And that any additional skills or knowledge acquired by an individual will produce an additional income in terms of higher earnings, hence, the justification for individuals to invest in getting additional knowledge and competences (Psacharapoulos and Patrinos 2004; Schiller and Liefner 2007). Kjelland (2008) further buttress the argument that education can be seen as an effort that gives an individual knowledge and competences which at the end that knowledge can enhance his human capital, which should be in terms of recognition and increased earnings and social wellbeing. Ahmed (2015) argue that investing in individuals through education should not just be look at in terms of private monetary reward the individual will get, but rather on how the society will benefit as a result of the spillover effect of such education given to the individual. This position justified why Government should be involve in financing and or provision of quality education. The fundamental principles HCT tries to explain was that investment in education has two distinct motive of private and public rate of return as it affect individual and the nation at large. The question posed by the theory is, who should invest more in education, an individual or the nation? Justifying who pays for the cost of education, a lot of researches has been conducted to justify who pays for education and especially higher education whose return on investment is much higher that the lower level of education (Atuahene, 2008).

A debate on investing in higher education by an individual or government to subsidies to education or who should bear the burden of the financial resources committed to education has filled the literatures and it has been perceived from neo-liberal economic model and market terms (Psacharapoulos and Patrrinos 2004). 
A number of researchers use the human capital theory as a framework in their research work see for example Psacharapoulos and Patrrinos (2004), Atuahere (2008), Kjelland (2008) etc. However Schiller and Liefner (2007) specifically argue that education has a social return or spillover to the beneficiary of that education which will invariably increase his chance of getting higher earnings that his counterpart who didn't have an additional knowledge, and he uses the human capital theory to explain why an individual who benefit should also contribute to the financing of the education. Obasi and Eboh (2002) uses the HCT approach to justify education financing which takes the point of view of the individual and private financing mainly by the argument of profitability to the student. Obasi and Eboh (2002) further stated that the unique nature of the "goods" produced by the HEIs and the cross-cutting nature of the beneficiaries underscore the strong rationale for cost sharing among stakeholders which mean the private and the public sector.

\section{Political Economy Theory}

This theory has been used for some decades to express the interrelationship between the political and economic affairs of the country (Javens and Javons 1965). Francois Quesnay was the first to introduce a scientific system into political economy in the mid eighteenth century stating that political economy is the science of managing the resources of a nation so as to provide wealth to its inhabitants. Smith (1776) says political economy looks at how the ownership of the means of production influenced past processes. According to Schauerle, (2007) the political economic theory gives an overview of how the theory combines with the methods influence's the political ideology of a given nation. The theory equally explain how the economy, law and politics work together for the benefit of the state and also how institutions develop in different strata of the social and economic systems of a given nation.

Political economy has been identified to be a very complex field which takes into account different interest group working together and competing for the same limited resources available to the state. 
Political economic theory also attempts to look at the relationship between participants in a particular setting and predict their optimal decision. Adam Smith is said to be a major contributor on the development of the political economic theory. The Political Economic theory argues that there is a positive relation between politics, economic and the social system and that higher education as part of the social system is not entirely independent. Hence, for higher education to be adequately funded, economic system must be able to generate enough revenue and the political system makes education to be its priority. Aina (2002) uses the "Political Economic Theory" to explain the problem of university financing in Nigeria. According to him political economic theory strikes a balance between how political system and economic forces determine how resources should be allocated to HEIs in order for them to carry out their primary functions of teaching and research. The theory also explain the realities of the specific political, economic and social matrix of the present policy environment in Nigeria, whereby economic depression, political instability and cuts in government expenditure, all impact on the higher education system. The political economy theory sees the different structures in the society, including the economic, political, social structure and the belief system as interacting and interdependent. Thus, the higher education system which is also a subsector is subjected to the influence of the superstructure which is the economic system.

\section{THEORETICAL APPLICATION IN FINANCING OF HIGHER EDUCATION}

In order to tackle and achieve the objective of the paper, one theory out of the three discussed above have been adjudged to be more inline in given a good explanation on the concept of higher education financing. The Theory is Human Capital Theory. The rationale for selecting human capital theory is based on the premise that education and higher education in particular has been considered as useful and profitable economic investments and that people and nation invest in education to benefit from it at the end of it all. The main objective of allocating resources to education is to gain the pure economic benefits than can be measured and valued in monetary terms.

When an individual commit a lot of his monitory resources and sacrifices some time to obtain earned additional qualification, mostly they are mainly motivated by the expectation of high earning at the end of it. 
Similarly, when government decides to allocate resources to education in general or to higher education in particular, they expect that the resources invested will have a positive contribution to economic growth. The above premise therefore justifies the reason why government or individual invest in education and higher education in particular. Human capital theory makes an in depth explanation on this in which the other two theories; political economic theory and principal agency theory did not. Hence, the adoption of the theory to explain who should finance education and higher education in particular, the government or the individual or both?

Human Capital Theory: Education in general and higher education in particular are instruments for growth and very important for development in every civilization, based on its quality and quantity. For education to make a significant impact on economic growth and development, high quality and commitment is required. The $21^{\text {st }}$ century paradigm is shifting towards the improvement of knowledge as a priority for development the world over. This has been the main essence why many countries have to connect their higher education system more closely to their economic development strategies.

As stated by Schultz (1981) education is economic goods, this is because one cannot get it easily hence, very difficult to obtained and as a results the provision of education need to be apportioned. That is the reason why most economists in the world regard education as both a consumer and capital goods, because it offers utility (satisfaction) to a consumer and also serves as an input to develop the human resources necessary for economic and social transformation (Almendarez, 2013; Salawu, 2011). The emphasis on education as a capital goods, related largely to the theory of human capital, which underscores the importance of the development of skills in the production activities (Almendarez, 2010). His study further revealed that it is a known fact that education help in creating employment and improved citizens capacity to develop hence, helps to upgrade the general standard of living in a society.

The increased concern and belief in education as an agent of revolution in many developing countries, has led to substantial investments in it. 
In many developing countries pressure for higher education has absolutely been assisted by public awareness of financial reward from pursuing such education.

According to Almendarez (2010); Ahmed (2015) the economic success and functioning of any country depends to a larger extent on its physical and human capital stock. They further state that physical capital has then been the focus of economic research as a major factor in production. However, nowadays individual skills and abilities are progressively figured as another form of capital more especially in social and behavioral sciences researches. General as postulated above by many scholars, investment in human capital ensure and increase high economic productivity of and individual and the nation at large. Hence, Tilak $(2008,2013)$ stated that the theoretical framework which should be adopted for the healthy acceptance of education and development policies would be human capital theory. The overall debate from a global perspective on reasonable resources allocation to Higher Education and the desire for government increase subsidies to education has been debated from neo-liberal economic models and market terms. Schultz (1961) has identified as to how the human capital theory was propounded in the early 1960s. Becker (1964) further developed the theory and brings out the tenants and principles of the theory clearly. The major tenants that underscore the significant of the theory in explaining resource allocation and investment in higher education is the private and public rate of returns that is due to individuals and the nation at large.

The modern development of human capital theory has been observed from the 1970's, when public finance to education started to decline because of the increasing demand from other social service sectors, like security, health and administrative expenses. The work of Schultz (1963); Blaug (1970); Psacharopoulos (1970) exposed the development and usefulness of human capital theory. Most of the empirical work on human capital theory by the above authors brings to light the benefit of investing in human capital. In simple terms their work explains the theory in explaining a significant relationship between investments in education and monitory and non-monitory returns.

The motive develops from the assumptions that people, and nations make rational choices and decision to invest in education and training which develop and enhance skills used to improve labor productivity. 
This in turn increases the level of income for the individual and promotes economic growth (Al-hajry, 2002). Rapid increase in the use of Human Capital Theory was seen after 1960, i.e. 1960-1970, which was described by Blang (1992) and cited in Ahmed (2015) as the golden period for the concept of human capital. He further state that by 1970's a new interest in this field prophase which create a serious dialogue which emanate between one group call "First generation" economists of education who are believe in how education contribute to economic growth, the individual (private) demand for education, labor market expectation and requirements and rate of return to investment in education, and other group called the "second generation" economist who are only interested on different ways financing education and the labor market segmentation. Ahmed (2015) opined that the main reason for this change is the massive expansion of the education systems in the western world, which have a serious consequence of causes both micro and macro-economic problems in the developing countries like Nigeria. Overall both Individuals and nations belief that investment in higher education has social and economic benefit; hence they invest in it to gain the maximum benefit.

Human capital theory explains higher education financing based on the assumption that society will invest or allocate more resources if it feels that there is going to be greater benefit at the end of it all. So, the individual he or she invests in higher education because he or she expects higher wage or earning and increase in social status. If at the end of it all higher education is perceived to yield more benefits to the individuals and societies than the costs, then more resources will be allocated or invested (see for example Schultz, 1961; Becker, 1964; Psacharopoulos, 1996; Tilak, 2004).

Human capital theory as postulated by Almendarez (2013) rests on the notion that education whether formal or informal is highly influential and essential to develop the productive ability of a population. In short, Human capital theorists argue strongly that population that is educated is a productive population. Sidorkin (2007) and Almendarez (2013) posit that HCT emphasized on how an increase in the level of education can increases the productivity and efficiency of an individual employee by increasing the level of intellectual standard of economically productive human capability, 
Which is a product of innate abilities and investment in human beings. Woodhall, (1997) agree with the above and said that formal education is seen as an investment in human capital, which the tenets of the theory have considered as equal to the physical capital.

Human Capital Theory believes that investment in human capital will lead to greater economic outputs. However, Becker (1964) believe that physical assets like land, equipment and other tangible items in the past are considered to be the economic strength of any organization or even a nation. But with the evolution of the human capital theory labor was considered to be a necessary component, and it increases the value of the business even much more than the investment in capital equipment. Becker (1993) and Almendarez (2013) states that world intellectual economists agree that there is a positive correlation between education and health care and that they are key to improvement of human capital and thereby in turn influence greater economic outputs of the nation. In the view of the contemporary economy scholars, investing in physical assets may not be as essential as investing in human capital.

As postulated by Psacharopoulos (1996), in the western countries, formal education has in recent times been re-theorized under human capital theory as an economic device. The theory has been identified to be the most important economic theory that supports formal education, which helps the government to set policies and programs for the development of its citizenry since the early 1960s.

Sidorkin, (2007) Almendarez (2010) Ahmed (2015) Tilak (2013) Oyelere (2011) all posit that success of any nation in terms of human capital development is dependent upon the physical and human capital stock available for the smooth running of the economy of the country. Thus, in recent time's research in social science, Arts and humanities focuses on humanity in relation to economic productivity.

Hence, it lays more emphasis on human capital which represents the assets each individual develops to enhance economic productivity. Furthermore, most countries identified human capital to be more important in this era of technological advancement and globalization, 
Therefore countries and individuals employ the wholesome adoption of the policies of education and development very seriously to achieve success. In short, the human capital theorists argue that an educated person or an educated country is a productive person or a productive population (Kulvisaechana, 2006; OECD, 2013). This argument was agreed by Psacaropoulos (1996); Odior (2011). Davies (2003) posits that human capital theory providing a basic reason why education needs to have large public expenditure both in the developing and the developed nations.

Rapid economic growth has been associated with investment in human capital. For individuals, such investment is seen to provide high salary and improve social status. Most economists agree that it is human resources of nation that eventually determine the character and pace of its economic and social development (Becker, 1964; Schultz, 1963). According to Psacharopoulos (1970) Human resources establish the basis for economic growth and increase economic potential of the nations. Capital and natural resources are the ingredient for production while, human beings are the necessary active factors in the productive process.

Economists have identified education as economic goods because one cannot easily obtain it at will. So, there is the need to apportion it as education has been regarded by many economists as both a consumer and capital good. This is because education offers utility to an individual consumer and also functions as an input to develop the human resources necessary for economic and social transformation (Psacharopoulos, 1996; Almendarez, 2013). The concept of human capital has been seen as the main ingredient for economic and social development of a nation that only education can provide. The emphasis is that the improvement and development of requisite skills is very paramount and important factor in production activities which only education can provide. Education has been accepted globally as one of the factor that makes individual to improve in their social status and helps to upgrade the general standard of living in a society.

Heavy investment in education has been observed in most developed and developing countries which are borne out of the fact that education has been considered to be an agent of change by all. 
Pressures have been exerted on higher education in many developing countries because it has undoubtedly been helped by public perception of financial reward from pursuing such education.

According to Al-hjry (2002) the nations all over the world depend to a large extent on its physical and human capital stock to function effectively and compete in the global economy. He further states that most of the researches conducted in the recent years focus mostly on human capital simultaneously with traditional physical capital to have a balance in effective and efficient resource utilization, factors affecting the enhancement of human skills and talent are increasingly outlined in the research of social and behavioral sciences. This agrees with what Schultz (1981) and Tilak (2008) said that in general terms, human capital represents the investment people make in them that enhances their economic productivity.

From the fore-going discussion, it is certain to say that human capital theory is the most influential economic theory of the developed as well as the developing countries for setting policy framework and improve investment on education in order to have better economic performance since early 1960's. As can be seen from the Global Competiveness Index (GCI) (2014), the overall performances of the countries weigh more directly upon their knowledge stock and their learning capabilities. The theory proclaims that human behavior based on the economic self-interest of the individual operating within freely competitive market and education helps to increase labor productivity (Tilak, 2004; Becker, 1964). Human capital theory has been mostly applied to studies on the rate of return to education in the labor market perspective considering both the private and the public rate of return, see for example the work of Becker (1964); Glewwe (1996) Psacharopoulos (1996).In their work Mincer (1975); Schultz (2004) it reveals that additional year of schooling can affect individual earnings.

According to Mincer (1975) decision on investment in human capital is similar to decision on other physical investment.

This is because it generates growth and personal well-being and it has also positive and negative consequences in terms of return on investment. 
This clearly shows the benefit of investing in education. Mincer's study brings to light how investing in schooling affects individual earnings over the past three decade and how his work as well correlates schooling, experience and earnings which have a causal relationship in labor market. The future earnings will be based on years of schooling and their particular experience in labor market and more schooling is associated with individual's higher earnings. This argument by Mincer justifies the higher rate of return to the individual student through increase in earnings, which justified the reason why he (the individual student) should be prepared to pay for any additional year of study he gets.

Based on the importance attached to education, the discussion on human capital has been brought forward by many scholars. Studies have revealed an improvements in the productivity of individuals as a result of an additional qualification obtained, it also contribute to the development of technology, thus improving human capital (Hanushek and Wobmann,(2007);Kjelland, (2008). Schultz (2004) affirms that more than anything else, human capital development has been the reason for spectacular growth in East Asia. Countries such as Singapore and Hong Kong, have achieved a reasonable rates of economic growth while making large investments in education to improve human capital. World Bank (2010) found that improvement in education is a very significant explanatory variable for a nation economic growth. The spillover effects of educating an individual by the society are seen in healthy society, educated and enlightened society and politically and socially stable society and as well it promotes social change and technological advancement, hence, a good reason for the government to subsidize education. It should be noted that the higher salaries associated with higher degrees is just a micro aspect of financing higher education. But according to Atuahene (2008), if one would exclude externalities or spillover, then private rate of return may well be higher than the social rate of return to education and vis-à-vis.

Human capital theory is one of the theories that is relevant for this study, hence, the researcher cites some of the literature that uses the theory as a framework which include Psacharapoulos and Patrrinos (2004) as cited in Ahmed (2015) posit that the there is a significant increase in the earnings of a university graduate with the additional qualification earned compared non graduate and without experience. 
They summarize the rate of returns to education in developing countries mostly in Sub Saharan where policy and international aid is higher in primary and secondary education but in contrast, the investment in higher education remains trivial which have resulted in lower rates of return in higher education. The summary of their study was presented as: (i) Rate of return to education is generally higher than opportunity cost of capital for all levels of education. (ii) The rate of return to education is higher in the developing countries than in the developed countries, particularly in Sub Saharan Africa. (iii) The rate of return for primary education is the highest, followed by secondary education and then higher education (iv) Private rate of return is much higher than the social or the public rate of return at all levels of education. (v) The trend remains generally stable during a country's development even though there is a small decline in the rate of return to education.

Diagne and Diene (2011) consider the role of human capital on economic growth, with the emphasis on its productive effects and the determinants of human capital accumulation. They found out that in 28 studies, an additional year of education leads to five percent increase in income, with a median effect of four percent. The average benefit of an additional year of secondary education was 14 percent, with a median of 12 percent. They also listed 16 studies which, respectively found 37 and 30 percent for average and median effects of higher education. Private return to education estimate in microeconomics studies explains a clear indication of the positive impacts for the individual's well-being in low income countries, mostly in Sub Saharan Africa. However, it is more difficult to illustrate exact impact of education on production or in economic growth because often the developing countries and the rest of the Sub Saharan Africa have achieved private return to education through non-productive activities. The results show the different amounts because of methodological differences.

Kjelland (2008) found that human capital theory argues that education enhance the productivity of an individual and hence, increased his productivity which results in his increased earnings in the labor market. Since that being the contingency, Then there is need for that individual to also contribute toward financing the higher education system that produced him. 
The author uses the human capital theory to explain the economic returns to higher education. Schiller and Liefner (2007) argue that education has a social return or spillover to the individual in the form of higher earnings. They use human capital theory to explain the reason why an individual who is benefited should also contribute to the financing of his education. Obasi and Eboh (2002) uses the human capital theory approach to justify education financing which takes the point of view of the individual and private financing, mainly by the argument of profitability to the student. Obasi and Eboh (2002) further stated that the unique nature of the "goods" produced by the university education and the cross-cutting nature of the recipients emphasize the strong reason for cost sharing among stakeholders, the private and the public sector.

The study of rate of return is of paramount importance in studying higher education financing. This is because it gives a clear perspective as to who should pay for higher education based on the level of return earned between social and private return. Nowadays research reveals that the demand for educated workers for white collar job in the public as well as the private formal sector is drastically high ${ }^{1}$. The study conducted by Lassibilla and Tan (2005) in the post-genocide period in Rwanda shows that a person with higher education has a probability of working in the public sector that is nearly 37 times higher salary than a person who only has primary education and a person who have secondary education more than twice higher salary. Furthermore, the returns to education increased with the level of education and a return to higher education is particularly high. As discussed earlier on schooling in higher education, the private returns to education for an extra year of schooling in higher education is an average of 17.5 percent, whereas the rate is 19.4 for primary education, 29 percent for junior secondary education and 33.3 percent in senior secondary education. In the formal sector, the returns to primary education, vocational and secondary education fetch high margin whereas corresponding returns for higher education is high in the contemporary sector.

According to Sianesi and Reenen (2000) a report by OECD it shows that social rates of return in different levels of education are consistently found to be lower than those of private rates.

${ }^{1}$ see for example Lassibilla \& Tan, 2005; Kazianga, 2004 \& Oyelere, 2011 
In general, almost all the differences between the social and private rates of return are due to the cost associated in undertaking of additional year of schooling. Also Psacharopoulos (1996) and World Bank (2010)states that in Sub Saharan Africa and Latin America, where educational attainment ranges between six and eight years, one dollar of investment in schooling returns more than 12 percent annually in the form of increased wage rates. A study conducted by Foltz and Gajigo (2012) using three nationally repetitive household of 1992, 1998 \& 2003 surveys demonstrate that the private rates of returns are quite high although, heterogeneity in returns to education has occurred across regions of the country, the estimate of rate of returns to education on an additional year of schooling is 24.1 percent but in most regions the rates ranges from eight to sixteen percent whereas males returns of35.8 percent is comparatively higher than the female returns rate of 16 percent. According to this study, the aggregate private rate of returns in developing countries is higher in general usually in Africa. In the Gambian context it has shown that there is a high rate of return to education than the rest of the other developing countries of Africa.

Oyelere (2011) documented that the evidence of empirical study returns to education were low in Nigeria during the military era in the 1990s whereas, the low return have been broken down when democracy was restored in 1999. According Oyelere (2011) a significant high return to education was experienced because of rapid policy and institutional reforms in Nigeria by re-establishing the inclusive political and economic institutions that helped to bring better investment and other subsidies. The study was based on instrumental variables which have shown that returns to higher education increased by 6.3 percent more than the 1.3 percent and the 1.4 percent of the secondary and the primary education rates of return. The wage reform policy implemented in 1999 played a significant role to higher increase in returns for government workers with higher demand of skilled workers. Her study concludes first, that low returns to education in Nigeria in the 1990 during the military era could be explained in part by institutions and policy choice. 
Secondly, positive economic and political reforms can increase the return to education. Thirdly, she said that democratic reform can lead to an increase in the returns to schooling.

The literature cited on return to human capital generally focuses predominantly on assessing the return to education as a result of additional years of schooling. As summarize by Psacharopoulos (1994) he compiled the results from some countries in Asia, Africa and Latin America, individual salaries and wages, the studies comprises of 55 countries across the globe the summary presents a consistent pattern of very large return to primary education and a smaller returns to secondary and higher education. Psacharopoulos (1994) further stated that the average private rate of return to primary education in developing countries is 29 percent, while the returns to secondary and higher education are 18 and 20 percent respectively. The main problem with the focus of these studies is that the majority of individuals in developing countries are not wage earners. For example about 20 percent of working class individuals in Ghana are wage earners. Similarly, wage earners make up to 20 percent in Nigeria, 11 percent in Togo and India has 15 percent (World Bank,2010).

\section{CONCLUSION}

Theoretical and empirical views discussed in this paper relate to the financing of higher education which is the broad areas of this paper. The concept of higher education financing is defined based on a more theoretical and empirical standpoint. Furthermore the current global debate on whether higher education is a "public" or a "private goods" were elaborated and corroborated with a relevant theory and empirical discussion. An attempt was also made to take clues from the findings of some researches that had used the theories independently and identified them as relevant to the discussion. The review in the above paper reveals that the real development of human capital theory started during the 1960's. However, since then, a lot of theoretical discussions and empirical analyses covering a wide range of issues related to the development of human capital have been produced in many developed and developing countries. Most of the studies concentrated on the importance of human capital in developing education and the economy at large. 
Therefore, the paper discussed in detail the empirical findings and corroborates with the existing literature on financing higher education and builds on what the theoretical paper already highlighted.

\section{REFERENCE}

Abraham, M.G.(2012).Output-based funding viewed from practitioner perspective: the case of University of Nordland; Bodo graduate school of business.

Ahmad, A., Farley, A.and Naidoo, M.(2012).Analysis of government-university relationship form the perspective of agency theory. Journal of Education and Practice, $3(6), 12-21$

Ahmed, S. (2015). Public and private higher education financing in Nigeria. European Scientific Journal, 11(7), 92-109.

Aina, O.I. (2002).Alternative modes of financing higher education in Nigeria and the implications for university governance. Higher Education, XXVII(152),9136262.

Al-hajry, A.S. (2002).Human capital theory and financing of higher education in Oman. Unpublished doctoral dissertation,University ofSheffield, England, UK.

Almendarez, L. (2010, November 21-24).Human capital theory: Implication for educational development. Paper presented at Belize country Conference Belmopan, Belize, Central America.

Almendarez, L. (2013). Human capital theory: Implication for educational development in Belize and the Caribbean. Caribbean Quarterly, 59(3/4), 71-84.

Atuahene,F.(2008).The challenges of financing higher education and the role of students loan scheme: An analysis of the student loan trust fund (SLTF) in Ghana. Higher Education, 6(4), 407-421.

Babalola, J.B. (1998).Cost and financing university education in Nigeria.Higher Education, 36(1), 43-66. 
Becker, G. S. (1964).Human capital. USA: Princeton University Press.

Becker, G. S. (1993). Human capital: Atheoretical and empirical analysis with special reference to education ( ${ }^{\text {rd }}$ Eds), Chicago: University of Chicago Press.

Bendor, J., Glazer, A.and Hammond, T.(2001). Theories of deregulation.Annual Review Political Science, 4(1), 235-269.

Blalark, F.J.(2012).Utilizing Principal-Agency Theory and data environment analysis to examine efficiency of resource utilization in undergraduate education for public and private nonprofit four-year research Universities. Unpublished doctoral dissertation,University of Minnesota, USA.

Blaug, M. (1970).Introduction to the economics of education. Baltimore: Penguin Books.

Braendle, U. (2004). Theories of the Firm.Quarterly journal of Economics.3 (1), 141-154.

Chandrasiri, S. (2003).Financing of university education in Sri Lanka.Higher Education, 45(1), 91-108.

Chandrasiri, S. (2013). Innovative strategies in higher education for accelerated resource development in South Asia. Sri Lanka country report. ADB Publication.

Daniel, S. and Ingo, L.(2007).Higher education funding reform and university-industry links in developing countries: The case of Thailand. Higher Education,54(4), 543-556.

Davies, J. (2003). Empirical evidence on human capital externalities. Working paper 2003 (11). Department of economics university of Western Ontario, London, Canada N6A 5C2.

Diagne, A. and Diene, B. (2011). Estimating returns to higher education: A survey of models, methods and empirical evidence. Journal of African Economics Vol. 20 No. 3

Dirks, A.L. (1998). Higher education in marketing theory: Published by the author onLine (http://webhost.bridgew.edu/adirks/ald/papers/mktheor.htm). Bridgewater, MA. Retrieved on 19/12/13. 
Eisenhardt, M. (1989). Agency Theory: An Assessment and Overview.The Academic Journal of anagement Review, 14(1) 57-74.

Foltz, J.D. and Gajigo, O. (2012). Assessing the returns to education in the Gambia. Journal of African Economics, 21(4), 580-608.

Glewwe, P.W. (1996). The relevance of standard estimates of rates of return to schooling for education policy: a critical assessment. Journal of Development Economics,51(2) $\quad 267 \quad-290$.

Global Competitiveness Index [GCI] (2014). The World economic forum retrieved January 2, 2015 from www.weforum.org/gcr.

Hanushek, E. and Wossmann, L. (2007). The role of education quality in economic growth. The World Bank policy research working paper 4122. Washington D.C.

Ingo, L.(2003).Funding, resource allocation, and performance in higher education systems. HigherEducation,46(4), 469-489.

Javens, W.S.and Javons, H.S. (1965). The theory of political economy'. Fifth edition. Augustus M. Kelley Bookseller: New York.

Johnes, G. and Johnes, J. (1994).Policy reforms and the theory of educational finance. Journal of Economic Studies,21(1),3-15.

Kazianga, H. (2004). Schooling returns for wages earners in Burkina Faso. Economic growthCentre, Yale University. Discussion Paper 892. Retrieved August 1, 2014 from www.spears.okstate.edu/eclsworking-papers/files/0903-kazianga-education homerisk.pdf.

Kiker, B.F. (1966). The historical roots of the concepts of human capital. Journal of Political Economy, 74 (5),481-499.

Kivisto, J.(2005).The government-higher education institution relationship: Theoretical considerations from the perspective of agency theory.Tertiary Education and Management,11(1), 1-17. 
Kjelland, J.(2008). Economic return to higher education. Signaling vs. human capital theory; an analysis of competing theories. The Park Place Economist,16(1), 69-77

Kulvisaechana, S. (2006). Human capital development in the international organization: Rhetoric and reality. Journal of European Industrial Training,30(9), 721734.

Lane, J. E.and Kivisto, J. A. (2008). Interest, information, and incentive in higher education: Principal-agent theory and its potential applications to the study of higher education governance.Higher Education, 23, 141-156.

Lassibilla, G. and Tan, J.P. (2005).The return to education in Rwanda. Journal of African Economies, 14(1), 92-116.

Marshal, A. (1961).Principles of economics. $9^{\text {th }} E d$. London: The Macmillan Co.

Mincer, J. (1975). Education, experience, and the distribution of earnings and employment: An overview. In Thomas, F.J. (ed.) Education income and human behavior. NBER, pp. 71-94. Retrieved November 1, 2014, from www.nber.org/chapters/c3693.pdf.

Obasi, I.N.and Eboh, E.C. (2002). Cost sharing crises in Nigerian universities: Policy lesson from an empirical study. An essay submitted to the secretary general, Association of African Universities, PO Box 5744, Accra Ghana, under the $2^{\text {nd }}$ phase of the program of research on higher education policy and management.

Odior, E.S.O. (2011).Government spending on education, growth and long waves in a CGE micro simulation analysis: the case of Nigeria. British Journal of Economics, Finance and Management Sciences, 1(2), 74-87.

OECD (2013). Education at a Glance 2013. OECD indicators, OECD publishing. Retrieved March 2, 2014, from www.oecd.org/edu/eag2013(eng)--FINAL. 
Oyelere, R.U. (2011). Have returns to education change in Nigeria? Uncovering the role of democratic reforms. Journal of African Economies,20(5),737-780.

Psacharopoulos, G. (1970). Estimating shadow rates of return to investment in education. Journal of Human Resource. 5(1), 34-50

Psacharopoulos, G.(1996). Public spending on higher education in developing countries: Too many rather than too little. Economics of Education Review.15(4), 421-422.

Psacharopoulos, G.and Patrinos, H.A.(2004).Return to investment to education: a further update. Journal of Education Economics, 12(2), 111-134.

Salawu K.M (2011, November 9-11).Optimizing human capital and entrepreneurship: case study of Nigerianwomen.Paper presented at the $10^{\text {th }}$ International Entrepreneurship Forum, Tamkeen, Bahrain.

Schauerle M. (2007). History of political economy: An overview. Chapter one of Keizaigaku Shai (history of political economy). Tokyo: iwanami sholen.

Schillers, D.and Liefner, I.(2007).Higher education funding reform and universityindustry, linksin developing countries. The case of Thailand.Higher Education, 24(4), 543-556.

Schultz, T. W. (1963).Theeconomic value of education. USA: Columbia University Press.

Schultz, T. W.(1961). Investing in human capital. The American Economic Review, 51(1), pp. $\quad 1-17$.

Schultz, T. W.(1981).Investing in people. USA: University of Chicago Press.

Sianesi, B. and Reenen, J. V. (2000).The returns to education: a review of the macroeconomic literature. [Online]. London: LSE, research online. Retrieved June 2, 2014, from http://www.eprints.ise.ac.uk/archive00000781.

Sidorkin, M.A. (2007). Human capital and the labor of learning: a case of mistaken identity. Educational Theory,57(2), 159-170

Smith, A. (1776).The wealth of nations. Penguin books, edition 1973, edited by Andrew Skinner, England. 
Tilak, J.B.G and Varghese, N. V. (1991).Financing higher education in India. Higher Education, 21(1), 83-101.

Tilak, J.B.G.(2004). Higher education between the State and the market.Quarterly Review of Education(Unesco), 21(2), 227-39.

Tilak, J.B.G.(2008). Higher education: A public goods or a commodity for trade? Commitment to higher education or commitment to higher education trade.In Prospects, 38, Pp. 449-466

Tilak, J.B.G.(2013). Financing higher education in Sub-Saharan Africa. Africanus, 41(2),

\section{4-31}

Woodhall, M. (1997). Human capital concepts. Education, culture, economy and society, 3(2), pp. 219-223.

World Bank,(2010). Financing higher education in Africa, the World Bank, Washington D.C

Copyright (C) 2021 Sani Ahmed Yauta, AJRSP. This is an open-access article distributed under the terms of the Creative Commons Attribution License (CC BY NC). https://doi.org/10.52132/Ajrsp/en.2234 